\title{
Clothing problems and expectations of pregnant women
}

\section{Hamile kadınların giyim problemleri ve beklentileri}

\author{
Hande Ecem Buluş ${ }^{1}$ \\ Meyrem Arga Şahinoğlu ${ }^{2}$
}

Özet

Pregnancy period is an important and special process due to the physiological, psychological, social changes that occur before and after birth and the change in body appearance. In this process, it is very important for pregnant women to look beautiful in clothes and feel comfortable. Accordingly, it is aimed to determine the preferences, problems and expectations of pregnant women regarding pregnant clothes.

Pregnant women living in Ankara province are the population of the research using screening method; the sample consists of 247 pregnant women selected by the purposive sampling method. A questionnaire was prepared to collect data in the research. The data obtained as a result of the survey were analyzed using statistical methods and interpreted over tables. As a result of the research; pregnant women are expensive when purchasing maternity clothes and are not suitable for the body; while using maternity clothes, it is concluded that the colors of the fabrics fade and whether the clothes can be worn comfortably or not.
Hamilelik dönemi, doğum öncesinde ve sonrasında yaşanan fizyolojik, psikolojik, sosyal değişimler ve vücut görüntüsünde yaşanan değişiklik nedeniyle önemli ve özel bir süreçtir. Hamile kadınların bu süreçte giysilerin içinde güzel görünmek ve kendilerini rahat hissetmeleri oldukça önemli olmaktadır. $\mathrm{Bu}$ doğrultuda hamile kadınların hamile giysilerine ilisskin tercihleri, sorunlar1 ve beklentilerinin belirlenmesi amaçlanmaktadır.

Tarama yönteminin

kullanıldığ araştırmanın evrenini, Ankara ilinde yaşayan hamile kadınlar; örneklemini ise amaçlı örnekleme yöntemi ile seçilen 247 hamile kadın oluşturmaktadır. Araştırmada veri toplamak amacıyla anket hazırlanmıștır. Anket sonucunda elde edilen veriler istatistiksel yöntemlerden faydalanılarak analiz edilmiş ve tablolar üzerinden yorumlanmıştır. Araştırma sonucunda; hamile kadınların, hamile giysisi satın alırken pahalı olması ve vücuda uygun giysi olmamas1; hamile giysisi kullanırken ise, kumaşların renklerinin solması ve giysilerin rahat giyilip çıkarılmaması konularında sorun yaşadıkları sonucuna ulaşılmıştır.

\footnotetext{
${ }^{1}$ Ph.D. Student in Fashion Desing Department, Ankara Hacı Bayram Veli University, Graduate Education İnstitute, hndecmbulus@gmail.com ${ }^{1}$

${ }^{2}$ Assoc. Prof. Dr., Ankara Hacı Bayram Veli University, Faculty of Art and Design, Fashion Design Department, meyrem.arga@,hbv.edu.tr
} 
Buluş, H. E., \& Arga Şahinoğlu, M. (2020). Hamile kadınların giyim problemleri ve beklentileri. Journal of Human Sciences, 17(2), 659-672. doi:10.14687/jhs.v17i2.5985

Keywords: Fashion, Clothing, Maternity Anahtar Kelimeler: Moda, Giyim, Hamile Clothes, Pregnancy, Clothing Expectations and Giyimi, Hamilelik, Giyim Beklentileri ve Problems. Problemleri.

(Extended English summary is at the end of this document)

\section{GİRİS}

Giyim, tüketimin en görünür biçimlerinden biri olarak, kimliğin oluşmasında önemli bir rol oynamaktadır (Crane, 2003, s. 11). Kişilerin kimliğini ortaya koyma faktöründe, moda eğilimleri ve toplumsal etkenler rol oynamaktadır. (Koca, 2007, s. 19). Giysi tercihlerinde kişilerin sosyal çevreleri, yaşam şekilleri, kişilik özellikleri, aile gibi sosyal faktörler ve ekonomik, teknolojik ,politik faktörler de ön plana çıkmaktadır. Aynı zamanda giyim, sosyal statüyü yansıtan önemli faktörlerden birisidir (Ünal ve Özdoğan, 2009, s. 25). Giyim, kişilerin kimliğini ortaya koymasının yanında estetik, fonksiyonel ve tasarımılla ilgili olarak bireyde yarattığı etkiler açısından ele alındığında ergonomik terimler arasında da yer alır (Koca, 2007, s. 19). Insan hayatında önemli bir yere sahip olan giyim, hamilelik sürecinde de önemli bir kavram olarak karşımıza çıkmaktadır.

Hamilelik süreci, kadınların anneliğe ilk adımlarını attı̆̆ı önemli bir süreçtir. Birçok hamile kadın bu süreci yeni bir başlangıç olarak görmektedirler. Hamilelik kadınların vücudunda anatomik, fizyolojik, biyokimyasal, hormonal, mental değişimlerin gözlendiği belirli bir dönemidir. Stern ve Bruschweiler-Stern'e (1998) göre, bir kadının anne olması, hamileliğin en başından başlayarak doğum sonrasinda devam eden ve her hamilelikte yenilenen dinamik bir süreçtir (Demirlikan, 2015, s. 6).Hamilelik süreci yaklaşık olarak 280 gün veya 40 hafta olmaktadır. Bu süreç, 9 ay \pm 10 güne karşlık gelmektedir (Daloğlu, 2012, s. 4). Gebelik süresi kadında yaklaşık 40 hafta kabul edilir ve bu süreç trimestriler denen üç zaman aralığında ele alınır. Her dönem 13 haftadan biraz daha uzundur. İlk trimestri 0-13 hafta, ikinci trimestri 13-26 hafta, üçüncü trimestri 26-40 hafta olarak belirlenmiştir. 37-42 hafta arasına term denir ve normal doğum bu süre sonunda gözlenir (Üstdal ve Özgüven, 1997, s. 42). Hamile kadınlar, birinci trimester döneminde ambivalan (zit duygular) içerisindedirler. İkinci trimester döneminde ise meydana gelen fiziksel değişiklikler ambivalan duyguların ortadan kalkmasını hızlandırmaktadır. Hamile kadınlar kendilerini daha iyi hisseder ve olumlu duygular geliştirirler. Bu dönemde, gebe bir kadın görünümü kazanmıştır. Üçüncü trimester döneminde fiziksel olarak görünümü büyümüş ve hantallaşmıştır. Daha çabuk yorulurlar ve yeni beden görüntülerine uyum sağlamakta güçlük çekerler. Bu sorunlar günlük yaşamı da zorlaştırmaktadır (Aktan, 2015, s. 11,12).

Fiziksel değişim ilk belirtisi karın büyümesi ile birlikte kilo alımıdır. Hamile kadınların vücutlarında meydana gelen değişim giyim tercihlerini ve giyim alışkanlıkların da etkilemektedir. Bir kadının gebelik süresince, karın duvarına ve kalçalarına, 4 ile 4,5 $\mathrm{kg}$ arasında yağ birikmesi sonucunda anne adayının vücut ölçülerinin değişimine bağlı olarak giysi tercihleri ve giysi beklentileri de değişmektedir (Selvioğlu, 2011, s. 1).

Hamile giysileri, hamile kadınların hamilelik süreçlerini rahat geçirmeleri için tasarlanan özel giysilerdir. Hamilelik sürecinde kadınlar birçok psikolojik ve duygusal sorunlar yaşamaktadırlar. Bu dönemde hamileliğin özellikle ilerleyen aylarında vücudu değişime uğrayan kadının kendisini, şık, rahat ve mutlu hissedeceği giysiler bulması çok önemlidir.

Fonksiyonel gerekliliği olan hamile giysileri, genellikle kadınların hamilelik süresince değişen vücut şekillerine göre tasarlanmıştır. Fonksiyonel işlevinin yanı sıra hamile giysilerinin önemli psikolojik ve ideolojik işlevleri de vardır. Antik dönemden bugüne kadar kadın açısından hem kişisel hem de toplumsal olarak anneliğin oluşumunda hamile giysileri önemli bir unsur olmuştur (Günbulut, 2016, s. 32). 
Hamilelik sırasında bir kadının vücudunun fiziksel görünümünde belirgin bir değişiklik olmaktadır. En belirgin değişiklik, önemli kilo artısı, karın bölgesinde genişleme, gövde, kalça ve uzuvların kalınlaşmasıdır. Fiziksel değişiklikler, özellikle hamileliğin dördüncü ayında gardırop değiştirme ihtiyacına yol açmaktadır (Popescu, Mocenco, Olaru,s.67). Bu aylardan sonra ilk aylara oranla kilo artışı hızlanmakta ve vücuttaki fiziksel değişiklikler artmaktadır. Değişen bu vücut yapısına uygun giysilerin artık giyilmesi gerekmektedir. Bu dönemde değişen vücut yapısına uygun giysilerin kullanımı anne ve bebek sağllğı üzerinde büyük bir etkiye sahiptir. Ayrıca hamilelik sırasında iyi görünmek, kişinin kendisini her açıdan daha iyi hissetmesine de yardımcı olacaktır. Kadınlar, bu dönemdeki giysilerini her zaman olduğu gibi sosyal statü, kişisel özellikler, yaş, eğitim ve ekonomik olanaklarına bağlı olarak belirlemektedir. Bu konudaki en önemli nokta ise her kadının kendi zevk, ihtiyaç ve bütçe olanaklarına uygun giysiye kolayca ulaşabilmesi ve doğru seçimleri yapabilmesidir (Üstün, Çeğidir, A ̆gaç,2006,s.351).

\section{1) ÇALIŞMANIN AMACI VE ÖNEMİ}

Kadınlarda hamilelik süreçleri ile birlikte vücutlarında bazı değişiklikler meydana gelmektedir. Hamilelikte meydana gelen bu değişiklikler fiziksel ve duygusal değişiklikler şeklinde olmaktadır. Hamilelik sürecinde kadınlar ilk üç veya dördüncü aya kadar kıyafetlere ihtiyaç duymazken bundan sonraki süreçte ise vücuttaki kilo artışı ve fiziksel değişikliklerden dolayı hamile kıyafetlerine ihtiyaç duymaktadırlar. Hamilelik döneminde güzel ve iyi görünmek kişinin kendisini daha iyi hissetmesine neden olmaktadır. Hamile kadınlar, bu süreçte giysi satın alırken sosyal statüleri, kişisel özellikleri, yaş, eğitim ve ekonomik olanaklarına göre değişiklik gösterebilir (Güzel ve Mızrak, 2011, s. 59).

Hamilelik sürecinde vücut da fiziksel değişiklikler göz önüne alındığında özellikle çalışan hamile kadınların özel hamile giysilerine ihtiyaç olduğu gözlenmiştir. Hamile kadınların hamilelik süreciyle değişen vücut şekilleri ile kıyafetten beklentileri de değişiklik göstermektedir. Kıyafetin bedene uyum sağlamasıyla birlikte ergonomik ve fonksiyonel olması da büyük önem taşımaktadır (Selvioğlu, 2011, s. 3).

Türkiye'de canlı doğan bebek sayısı 2018 yllında 1 milyon 248 bin 847'dir. Toplam doğurganlık hızı, 2017 yılında 2,07 çocuk iken 2018 yılında 1,99 çocuk olarak gerçekleşti. Yani, bir kadının doğurgan olduğu dönem boyunca doğurabileceği ortalama çocuk sayıs1 1,99 oldu. Toplam doğurganlık hızı (çocuk sayısı), bir kadının doğurgan olduğu dönem (15-49 yaş grubu) boyunca doğurabileceği ortalama çocuk sayısını ifade etmektedir (Türkiye İstatistik Kurumu, 2019). Türkiye'de her yıl yaklaşık 1 milyon hamile kadın olduğu göz önüne alındığında, işlevsel giysi formunda tasarlanmış özel giysilere gereksinimi olan tüketici grubunun dikkate alınacak boyutta olduğu söylenebilir (Koca, 2007, s. 4). Bu potansiyel göz önüne alındığında, Türkiye'de hamile giyimi önemli bir pazar oluşturmaktadır.

Geçmişte hamile giysisi seçenekleri genellikle; Jean salopetler, robadan büzgülü jileler ve beli lastikli pantolonlarla sınırlı kalmıştır. Günümüzde artık bazı markalar, hamile giyimlerinin önemini fark ederek sezon eğilimlerini yansıtan spordan abiyeye, günlük giyimlerden ofis giysilerine kadar uzanan hamile koleksiyonlarını pazara sunmaya başlamışlardır. (Üstün, Çeğidir, Ağaç, 2006,s.350351). Ancak hazır giyim işletmeleri tarafindan oluşturulan koleksiyonların henüz geniş kitlelere yeterince ulaşamadığı, hamilelik dönemindeki anne adaylarının çoğunun ihtiyaçlarına cevap veremediği bilinmektedir.

$\mathrm{Bu}$ araştırmada, hamile kadınların hamile giysilerine ilişkin yaşadıkları sorunların ve beklentilerinin belirlenmesi amaçlanmaktadır. Bu amaçla aşağıda yer alan alt problemlere cevap aranmıştır.

1. Hamilelerin hamile giysilerine ilişkin tercihleri nelerdir?

2. Hamilelerin hamile giysilerine ilişkin yaşadığı sorunlar nelerdir?

3. Hamilelerin hamile giysilerine ilişkin beklentileri nelerdir? 
Hamile kadınların hamilelik döneminde giysilere ilişkin yaşadıkları sorunlar konusunda farkındalık oluşturması açısından önemlidir. Ayrıca hamile giysi üretimi yapan işletmelere yol gösterici nitelik taşıması çalışmanın önemini arttırmaktadır.

\section{2) YÖNTEM}

Hamile kadınların, hamile giysilerine ilişkin yaşadıkları sorunların ve beklentilerinin belirlenmesi amacıyla yapılan bu araştırmada tarama yöntemi kullanılmıştır. Tarama modeli, "geçmişte ya da halen varolan bir durumu var olduğu şekliyle betimlemeyi amaçlayan araştırma yaklaşımıdır" (Karasar, 2014, s. 77).

\section{1. Evren ve Örneklem}

Araştırmanın evrenini Ankara'da yaşayan hamile kadınlar oluşturmaktadır. Araştırmanın örneklemi olasıllğı bilinmeyen örnekleme yöntemlerinden amaçlı örnekleme ile belirlenmiştir. Bu tür örneklemede araştırmacı kimlerin seçileceği konusunda kendi yargısını kullanır ve araştırmanın amacına en uygun olanları örnekleme alır. Bazı alt kümelerin örneklemi genel hatlarıyla yansıttığı gözlenmişse, bundan sonra da yansıtacağı varsayımına dayalı olarak bu alt kümelerden örnekleme yapılır (Balc1, 2005, s.90). Araştırmanın örneklemi belirlenirken, hamile giysilerine hamileliğin yaklaşık dördüncü ayından itibaren ihtiyaç duyulmaya başlaması dikkate alınmıştır. Bu nedenle hamileliklerinin 2. ve 3 . trimester dönemlerinde olan hamile kadınlar araştırma kapsamına alınmıştır. Araştırmanın örneklemini hamileliklerinin 2. ve 3. trimester dönemlerinde olan toplam 247 kadın oluşturmaktadır. Araştırmaya katılan hamile kadınların demografik özellikleri incelendiğinde;

- \% 42.9’unun 29-38 yaş, \% 36.0'sının 19-28 yaş, \% 18.6'sının ise 39-48 yaş aralığında olduğu,

- \% 59,1'inin çalıştığı, \% 40,9'unun çalışmadığ1,

- \% 35.2'sinin lisans, \% 29.6'sinin lise, \% 18.2'sinin ön lisans, \% 8.9'unun ise yüksek lisans mezunu olduğu,

- $\%$ 73.7'sinin 3.Trimester döneminde, \% 24.7'sinin ise 2.Trimester döneminde olduğu,

- $\% 57.1$ 'inin 1 çocuk, \% 32.4'ünün ise 2 çocuk sahibi olduğu,

- \% 19.0’unun 3. ayda, \% 26.7'sinin 4. ayda, \% 34.0'ünün 5. ayda, \% 12.1'inin 6. ayda hamile giysisi aldıkları görülmektedir.

\section{2. Veri Toplama Teknikleri}

Araştırmada, konuya ilişkin ulusal ve uluslararası yazılı ve görsel kaynaklardan lireratür çalışması yapılmışıtır. Literatür taraması doğrultusunda tercih ettikleri giysi türleri, hamile giysisi temin etme şekilleri, hamile giysilerinde tercih ettikleri giysi özellikleri, giysi satın alırken ve kullanırken yaşadıkların sorunları ve hamile giysilerinden beklentilerini belirlemek amacıyla anket hazırlanmıştır. Anket iki bölümden oluşmaktadır. Birinci bölümde hamilelerin demografik özelliklerini belirlemeye; ikinci bölünde ise hamile kadınların tercih ettikleri giysi türleri, hamile giysisi temin etme şekilleri, hamile giysilerinde tercih ettikleri giysi özellikleri, giysi satın alırken ve kullanırken yaşadıkları problemleri ve hamile giysilerinden beklentilerinin belirlenmesine yönelik sorulara yer verilmiştir. Ankette yer alan likert tipi sorular 1=Katıllyorum, 2=Kısmen Katıliyorum, 3=Katılmiyorum ve $\mathbf{1 = O ̈ n e m s i z ~} \quad \mathbf{2 = K ı s m e n ~ o ̈ n e m l i ~} \quad 3=O ̈ n e m l i \quad 4=C ̧ o k$ önemli şeklinde derecelendirilmiştir. Anket, uygulanmasına izin verilen iki devlet hastanesinde kontrollerine devam eden hamile kadınlara araştırmacı tarafından uygulanmıştır. 
Buluş, H. E., \& Arga Şahinoğlu, M. (2020). Hamile kadınların giyim problemleri ve beklentileri. Journal of Human Sciences, 17(2), 659-672. doi:10.14687/jhs.v17i2.5985

\section{3. Verilerin Analizi}

Elde edilen veriler Sosyal Bilimler Paketi (IBM SPSS Statistics 20.0) kullanilarak analiz edilmiştir. Araştırmada anket sorularının ölçek güvenilirliğini/geçerliliğini belirlemek amacıyla Cronbach Alpha $(\alpha)$ test istatistiği sonuçlarına bakılmıştır. Cronbach Alpha Katsayısının değerlendirilmesinde uyulan değerlendirme ölçütü $0.80 \leq \alpha<1.00$ ise ölçek yüksek oranda güvenilir olmaktadır (Özdamar, 2002, s. 673). Araştırmada, yapılan Cronbach Alpha ( $\alpha$ ) istatistiği $=0.885$ olarak hesaplanmıştır. Anket aracilığıla elde edilen verilerin frekans ve yüzde dağılımları çapraz tablolarda verilmiştir. Hamile kadınların çalışma durumu ile tercih ettikleri giysi türleri, hamile giysisi temin etme şekilleri, hamile giysilerinde tercih ettikleri giysi özellikleri, giysi satın alırken ve kullanırken yaşadıkları problemler ve hamile giysilerinden beklentileri arasında istatistiksel ilişkinin ölçümü için ki-kare ilişki analizi yapılmıştır. Sonuçlar $\mathrm{P}<0.05$ anlamlılık düzeyinde yorumlanmıştır.

\section{3) BULGULAR}

Araştırmaya katılan örneklem grubunun; hamilelik süresince tercih ettikleri giysi türleri, hamile giysilerini temin etme şekilleri, hamile giysilerinde tercih ettikleri özellikler, hamile giysisi satın alırken ve kullanırken yaşadıkları sorunlar ve hamile giysilerinden beklentilerine ilişkin bulgulara aşağıda yer verilmiştir.

\section{1. Hamilelerin hamile giysi tercihlerine ilişkin bulgular}

Bu bölümde hamile kadınların hamilelik süresince tercih ettikleri giysi türleri, hamile giysilerini temin etme şekilleri ve hamile giysilerinde tercih ettikleri özelliklere ilişkin bulgulara yer verilmiştir.

Tablo 1: Hamile kadınların hamilelik sürecinde tercih ettikleri giysi türleri

\begin{tabular}{|c|c|c|c|c|c|c|c|c|c|}
\hline \multirow{2}{*}{\multicolumn{2}{|c|}{ Giysi Türü }} & \multicolumn{2}{|c|}{ Çalışmayan } & \multicolumn{2}{|c|}{ Çalışan } & \multicolumn{2}{|c|}{ Toplam } & \multirow{2}{*}{$z^{2}$} & \multirow{2}{*}{$\mathrm{p}$} \\
\hline & & Evet & Hayır & Evet & Hayır & Evet & Hayır & & \\
\hline \multirow{2}{*}{ Etek } & $S$ & 19 & 82 & 20 & 126 & 39 & 208 & \multirow{2}{*}{1.174} & \multirow{2}{*}{.279} \\
\hline & $\%$ & 18.8 & 81.2 & 13.7 & 86.3 & 15.8 & 84.2 & & \\
\hline \multirow{2}{*}{ Pantolon } & $S$ & 45 & 56 & 91 & 55 & 136 & 111 & \multirow{2}{*}{7.622} & \multirow{2}{*}{.006} \\
\hline & $\%$ & 44.6 & 55.4 & 62.3 & 37.7 & 55.1 & 44.9 & & \\
\hline \multirow{2}{*}{ Elbise } & $S$ & 30 & 71 & 69 & 77 & 99 & 148 & \multirow{2}{*}{7.663} & \multirow{2}{*}{.006} \\
\hline & $\%$ & 29.7 & 70.3 & 47.3 & 52.7 & 40.1 & 59.9 & & \\
\hline \multirow{2}{*}{ Jile } & $S$ & 8 & 93 & 13 & 133 & 21 & 226 & \multirow{2}{*}{0.074} & \multirow{2}{*}{.785} \\
\hline & $\%$ & 7.9 & 92.1 & 8.9 & 91.1 & 8.5 & 91.5 & & \\
\hline \multirow{2}{*}{ Tayt } & $S$ & 27 & 74 & 68 & 78 & 95 & 152 & \multirow{2}{*}{9.931} & \multirow{2}{*}{.002} \\
\hline & $\%$ & 26.7 & 73.2 & 46.5 & 53.4 & 38.5 & 61.5 & & \\
\hline \multirow[t]{2}{*}{ Slopet } & $S$ & 6 & 95 & 7 & 139 & 13 & 234 & \multirow{2}{*}{0.157} & \multirow{2}{*}{.692} \\
\hline & $\%$ & 5.9 & 94.0 & 4.79 & 95.2 & 5.3 & 94.7 & & \\
\hline \multirow[t]{2}{*}{ Gömlek } & S & 20 & 81 & 40 & 106 & 60 & 187 & \multirow{2}{*}{1.873} & \multirow{2}{*}{.171} \\
\hline & $\%$ & 19.8 & 80.1 & 27.3 & 72.6 & 24.3 & 75.7 & & \\
\hline \multirow[t]{2}{*}{ Bluz } & $S$ & 27 & 74 & 61 & 85 & 88 & 159 & \multirow{2}{*}{5.895} & \multirow{2}{*}{.015} \\
\hline & $\%$ & 26.7 & 73.2 & 41.7 & 58.2 & 35.6 & 64.4 & & \\
\hline
\end{tabular}

$\mathrm{n}: 247$

Hamile kadınların hamilelik sürecinde tercih ettikleri giysi türlerine ilişkin bulguların yer aldığ1 Tablo 1 incelendiğinde, \% 55.1'inin pantolon, \% 40.1'inin elbise ve \% 38.5'inin tayt tercih ettiği, üst 
Buluş, H. E., \& Arga Şahinoğlu, M. (2020). Hamile kadınların giyim problemleri ve beklentileri. Journal of Human Sciences, 17(2), 659-672. doi:10.14687/jhs.v17i2.5985

giyim olarak ise \% 35.6'sının bluz tercih ettikleri görülmektedir. En az tercih edilen üç giysi türünün ise salopet (\% 5.3), jile (\% 8.5) ve etek (\% 15.8) olduğu görülmektedir.

Mızrak ve Güzel’in çalışmasında, en çok tercih edilen giysi türünün etek ve pantolon olduğu belirlenmiştir (2011, s. 62). Kılıç, Tama ve Öndoğan'ın çalışmasında ise, tercih edilen giysi türlerinin pantolon, elbise ve etek olduğu; \%46'sının ise bu üç giysi türünü de kullanmayı tercih ettikleri belirtilmiştir (2014, s. 69). Bu sonuçların, yapılan araştırmanın sonuçlarını destekler nitelikte olduğu ve hamilelik döneminde tercih edilen pantolon, triko-penye ve elbisenin hareket kolayliğ1 sağladığ1 için tercih edildiği düşünülmektedir.

Yapılan Ki-Kare analizi sonucunda ise hamile kadınların çalışma durumu ile tercih ettikleri giysi türleri arasinda yer alan pantolon (.006), elbise (.006), tayt (.002) ve bluz (.015) arasinda istatistiksel olarak anlamlı bir ilişki olduğu görülmektedir.

Tablo 2: Hamile kadınların hamilelik sürecinde giysilerini temin etme yollar1

\begin{tabular}{|c|c|c|c|c|c|c|c|c|c|}
\hline \multirow{2}{*}{\multicolumn{2}{|c|}{ Giysi Temin Yolu }} & \multicolumn{2}{|c|}{ Çalışmayan } & \multicolumn{2}{|c|}{ Çalışan } & \multicolumn{2}{|c|}{ Toplam } & \multirow{2}{*}{$x^{2}$} & \multirow[b]{2}{*}{$\mathrm{p}$} \\
\hline & & \multirow{2}{*}{$\frac{\text { Evet }}{67}$} & \multirow{2}{*}{$\frac{\text { Hayır }}{34}$} & \multirow{2}{*}{$\frac{\text { Evet }}{124}$} & \multirow{2}{*}{$\frac{\text { Hayır }}{22}$} & \multirow{2}{*}{$\frac{\text { Evet }}{191}$} & \multirow{2}{*}{$\frac{\text { Hayır }}{56}$} & & \\
\hline \multirow{2}{*}{ Satın Alma } & $\mathrm{S}$ & & & & & & & \multirow{2}{*}{11.774} & \multirow{2}{*}{.001} \\
\hline & $\%$ & 66.3 & 33.7 & 84.9 & 15.1 & 77.3 & 22.7 & & \\
\hline \multirow{2}{*}{ Diktirme } & $\mathrm{S}$ & 19 & 82 & 15 & 131 & 34 & 231 & \multirow{2}{*}{3.666} & \multirow{2}{*}{.056} \\
\hline & $\%$ & 18.8 & 81.2 & 10.3 & 89.7 & 13.8 & 86.2 & & \\
\hline \multirow{2}{*}{ Ödünç Alma } & $\mathrm{S}$ & 13 & 88 & 25 & 121 & 38 & 209 & \multirow{2}{*}{0.829} & \multirow{2}{*}{.363} \\
\hline & $\%$ & 12.9 & 87.1 & 17.1 & 82.9 & 15.4 & 84.6 & & \\
\hline \multirow{2}{*}{$\begin{array}{l}\text { Hamilelik Öncesi } \\
\text { Giysileri } \\
\text { Kullanma }\end{array}$} & $S$ & 28 & 73 & 18 & 128 & 46 & 201 & \multirow[b]{2}{*}{9.335} & \multirow[b]{2}{*}{.002} \\
\hline & $\%$ & 27.7 & 72.3 & 12.3 & 87.7 & 18.6 & 81.4 & & \\
\hline
\end{tabular}

$\mathrm{n}: 247$

Hamile kadınların hamilelik sürecinde giysilerini hangi yol ile temin ettiklerine ilişkin bulguların yer aldığı Tablo 2 incelendiğinde, \% 77.3'ünün satın alma yoluyla temin ettikleri görülmektedir. Hamileliğin ilk üç veya dördüncü ayına kadar hamilelerin büyük bir çoğunluğu hamile giysilerine ihtiyaç duymamakta, bu aylara kadar daha önceki giysilerinin tamamından olmasa bile bir kısmindan faydalanabilmektedirler. Bu aylardan sonra ilk aylara oranla kilo ve vücuttaki fiziksel değişiklikler hızla artmakta (Üstün, Çeğidir ve Ağaç, 2006,s.351) ve yeni vücut yapısına uygun giysilere ihtiyaç duyulmaya başlanmaktadır.

Yapılan Ki-Kare analizi sonucunda ise hamile kadınların çalışma durumu ile giysi temin etme yolları arasında yer alan satın alma (.001) ve önceki giysileri kullanma (.002) arasında istatistiksel olarak anlamlı bir ilişki olduğu görülmektedir.

Tablo 3: Hamile kadınların giysi özelliklerine önem verme düzeyleri

\begin{tabular}{|c|c|c|c|c|c|c|c|c|c|c|c|c|c|c|c|}
\hline \multirow{2}{*}{\multicolumn{2}{|c|}{ Giysi Özelliği }} & \multicolumn{4}{|c|}{ Çalışmayan } & \multicolumn{4}{|c|}{ Çalışan } & \multicolumn{4}{|c|}{ Toplam } & \multirow{2}{*}{$\gamma^{2}$} & \multirow{2}{*}{$\mathrm{p}$} \\
\hline & & 1 & 2 & 3 & 4 & 1 & 2 & 3 & 4 & 1 & 2 & 3 & 4 & & \\
\hline \multirow{2}{*}{ Model } & $\mathrm{S}$ & 47 & 15 & 29 & 10 & 26 & 30 & 68 & 22 & 73 & 45 & 97 & 32 & \multirow{2}{*}{23.814} & \multirow{2}{*}{.000} \\
\hline & $\%$ & 46.5 & 14.8 & 28.7 & 9.9 & 17.8 & 20.5 & 46.5 & 15.0 & 29.6 & 18.2 & 39.3 & 13.0 & & \\
\hline \multirow{2}{*}{ Stil/Tarz } & $\mathrm{S}$ & 23 & 45 & 24 & 9 & 17 & 44 & 64 & 21 & 40 & 89 & 88 & 30 & \multirow{2}{*}{16.233} & \multirow{2}{*}{.001} \\
\hline & $\%$ & 22.7 & 44.5 & 23.7 & 8.9 & 11.6 & 30.1 & 43.8 & 14.3 & 16.2 & 36.0 & 35.6 & 12.1 & & \\
\hline \multirow{2}{*}{ Renk } & $\mathrm{S}$ & 28 & 28 & 34 & 11 & 30 & 32 & 67 & 17 & 58 & 60 & 101 & 28 & \multirow{2}{*}{4.350} & \multirow{2}{*}{.226} \\
\hline & $\%$ & 27.7 & 27.7 & 33.6 & 10.8 & 20.5 & 21.9 & 45.8 & 11.6 & 23.5 & 24.3 & 40.9 & 11.3 & & \\
\hline \multirow{2}{*}{$\begin{array}{l}\text { Kumaş } \\
\text { Özelliği }\end{array}$} & $\mathrm{S}$ & 19 & 34 & 25 & 23 & 13 & 24 & 71 & 38 & 32 & 58 & 96 & 61 & \multirow{2}{*}{21.081} & \multirow{2}{*}{.000} \\
\hline & $\%$ & 18.8 & 33.6 & 24.7 & 22.7 & 8.9 & 16.4 & 48.6 & 26.0 & 13.0 & 23.5 & 38.9 & 24.7 & & \\
\hline
\end{tabular}


Buluş, H. E., \& Arga Şahinoğlu, M. (2020). Hamile kadınların giyim problemleri ve beklentileri. Journal of Human Sciences, 17(2), 659-672. doi:10.14687/jhs.v17i2.5985

\begin{tabular}{|c|c|c|c|c|c|c|c|c|c|c|c|c|c|c|c|}
\hline \multirow{2}{*}{ Fiyat1 } & S & 15 & 34 & 37 & 15 & 12 & 41 & 65 & 28 & 27 & 75 & 102 & 43 & \multirow{2}{*}{4.556} & \multirow{2}{*}{.207} \\
\hline & $\%$ & 14.8 & 33.6 & 36.6 & 14.8 & 8.2 & 28.0 & 44.5 & 19.1 & 10.9 & 30.4 & 41.3 & 17.4 & & \\
\hline \multirow{2}{*}{$\begin{array}{l}\text { Kullanım } \\
\text { Kolaylığ1 }\end{array}$} & \begin{tabular}{l|l}
$S$ \\
\end{tabular} & 24 & 22 & 25 & 30 & 11 & 20 & 49 & 66 & 35 & 42 & 74 & 96 & \multirow{2}{*}{18.627} & \multirow{2}{*}{.000} \\
\hline & $\%$ & 23.7 & 21.7 & 24.7 & 29.7 & 7.5 & 13.6 & 33.5 & 45.2 & 14.2 & 17.0 & 30.0 & 38.9 & & \\
\hline \multirow[t]{2}{*}{ Bakım Kolaylığı } & \begin{tabular}{|l|}
$S$ \\
\end{tabular} & 20 & 35 & 29 & 17 & 14 & 35 & 60 & 37 & 34 & 70 & 89 & 54 & \multirow{2}{*}{11.446} & \multirow{2}{*}{.010} \\
\hline & $\%$ & 19.8 & 34.6 & 28.7 & 16.8 & 9.5 & 23.9 & 41.0 & 25.3 & 13.8 & 28.3 & 36.0 & 21.9 & & \\
\hline \multirow{2}{*}{$\begin{array}{l}\text { Giysinin } \\
\text { Rahatlloğ1 }\end{array}$} & \begin{tabular}{l|l}
$S$ \\
\end{tabular} & 14 & 27 & 24 & 36 & 11 & 17 & 40 & 78 & 25 & 44 & 64 & 114 & \multirow{2}{*}{14.386} & \multirow{2}{*}{.002} \\
\hline & $\%$ & 13.8 & 26.7 & 23.7 & 35.6 & 7.5 & 11.6 & 27.3 & 53.4 & 10.1 & 17.8 & 25.9 & 46.2 & & \\
\hline \multirow{2}{*}{$\begin{array}{l}\text { Modaya } \\
\text { Uygunluğu }\end{array}$} & \begin{tabular}{|l|l}
$S$ \\
\end{tabular} & 21 & 45 & 27 & 8 & 31 & 56 & 43 & 16 & 52 & 101 & 70 & 24 & \multirow{2}{*}{1.289} & \multirow{2}{*}{.732} \\
\hline & $\%$ & 20.7 & 44.5 & 26.7 & 7.9 & 21.2 & 38.3 & 29.4 & 11.0 & 21.1 & 40.9 & 28.3 & 9.7 & & \\
\hline \multirow{2}{*}{$\begin{array}{l}\text { Vücuda } \\
\text { Uyumu }\end{array}$} & S & 19 & 25 & 29 & 28 & 13 & 23 & 60 & 50 & 32 & 48 & 89 & 78 & \multirow{2}{*}{10.357} & \multirow{2}{*}{.016} \\
\hline & $\%$ & 18.8 & 24.7 & 28.7 & 27.7 & 8.9 & 15.8 & 41.0 & 34.2 & 13.0 & 19.4 & 36.0 & 31.6 & & \\
\hline \multirow{2}{*}{$\begin{array}{l}\text { Organik } \\
\text { Olmas1 } \\
\end{array}$} & $\mathrm{S}$ & 25 & 32 & 24 & 20 & 21 & 56 & 36 & 33 & 46 & 88 & 60 & 53 & \multirow{2}{*}{5.104} & \multirow{2}{*}{.277} \\
\hline & $\%$ & 24.8 & 31.7 & 23.7 & 19.8 & 14.4 & 38.3 & 24.7 & 22.6 & 18.6 & 35.6 & 24.3 & 21.5 & & \\
\hline \multirow{2}{*}{\begin{tabular}{l|} 
Hamilelik \\
Sonras1 \\
Kullanilabilmesi
\end{tabular}} & $S$ & 25 & 39 & 24 & 13 & 34 & 54 & 29 & 29 & 59 & 93 & 53 & 42 & \multirow{2}{*}{2.235} & \multirow{2}{*}{.525} \\
\hline & $\%$ & 24.8 & 38.6 & 23.8 & 12.9 & 23.2 & 37.0 & 19.9 & 19.9 & 23.9 & 37.7 & 21.5 & 17.0 & & \\
\hline
\end{tabular}

n:247 1.Önemsiz 2.Kısmen önemli 3.Önemli 4.Çok önemli

Hamile kadınların giysi özelliklerine önem verme düzeylerine ilişkin bulguların yer aldığı Tablo 3 incelendiğinde, \%46.2'sinin giysinin rahatlığı, \%38.9’unun kullanım kolaylı̆̆ı seçeneklerini 'çok önemli' bulduğu; \%41.3'ünün fiyat1, \%40.9'unun rengi, \%39.3’ünün modeli, \%38.9'unun kumaş özelliği, \%36.0’sısnın ise bakım kolaylığı ve vücuda uyumunu ‘önemli’ buldukları görülmektedir.

Selvioğlu'nun çalısmasında; hamile kadınların kumaşın, bakım kolaylı̆̆ının ve modelin önemli olduğunu belirttikleri görülmektedir. Araştırmada hamile kadınlar hamile giysilerinde modelin önemli olduğunu ifade ederken bunu rahatlık ile özdeşleştirmiş oldukları belirtilmektedir (2011,s30). Çeğindir, Üstün ve Ağaç’ın çalışmasında, en çok önemsedikleri özelliğin rahatlık olduğu görülmekte ve bunu ikinci olarak giysinin modeli takip etmektedir (2006) .

Yapılan bu çalışmada bunlara ek olarak hamile kadınların, hamile giysilerinin organik olmasına önem verdikleri de görülmektedir. Hamile kadınların giysilerinde kullanılan kumaşların anne ve bebek sağlığını doğrudan etkilediği bilinmektedir. Organik tekstil ürünleri, ham maddesi sentetik gübre, her türlü zirai ilaçlar kullanılmaksızın yetişen ve prosesi esnasında da sentetik kullanılmayan ürünlerdir (Demircanlı, 1998, s. 17). Hayatımızda gelişen teknolojiyle birlikte giren birçok kimyasal, gizliden gizliye yaşam kalitemizi bozan hastalıklara sebep olmaya başlamıştır. Vücuda giren zararlı ve yabancı maddelerin (toksinlerin) bir kısmı doğal yollarla atılırken bir kısmı vücut içinde kalmaktadır. Bu gelişmeler karşısında insanlar kullandıkları ürünlerin sağlıklarını tehdit etmemesini talep etmeye başlamışlardır (Türkdemir, 2013, s. 13).

Yapılan Ki-Kare analizi sonucunda ise hamile kadınların çalışma durumu ile hamilelik dönemi içerisinde giysi özelliklerine önem verme durumları arasında yer alan model (.000), stil (.001), kumaş Özelliği (.000), kullanım kolaylığ1 (.000), bakım kolaylığ1 (.010), giysinin rahatllğ1 (.002), vücuda uyumu (.016) ifadeleri arasında istatistiksel olarak anlamlı bir ilişki olduğu görülmektedir.

\section{2. Hamilelerin hamile giysilerinde yaşadıkları sorunlara ilişkin bulgular}

Bu bölümde hamile kadınların hamile giysisi satın alırken ve kullanırken yaşadıkları sorunlara ilişkin bulgulara yer verilmiştir. 
Buluş, H. E., \& Arga Şahinoğlu, M. (2020). Hamile kadınların giyim problemleri ve beklentileri. Journal of Human Sciences, 17(2), 659-672. doi:10.14687/jhs.v17i2.5985

Tablo 4: Hamile kadınların hamile giysisi satın alırken yașadıkları sorunlar

\begin{tabular}{|c|c|c|c|c|c|c|c|c|c|c|c|c|}
\hline \multirow{2}{*}{\multicolumn{2}{|c|}{ Problem Türü }} & \multicolumn{3}{|c|}{ Çalışmayan } & \multicolumn{3}{|c|}{ Çalışan } & \multicolumn{3}{|c|}{ Toplam } & \multirow{2}{*}{$z^{2}$} & \multirow[b]{2}{*}{$\mathrm{p}$} \\
\hline & & \multirow{3}{*}{$\begin{array}{c}1 \\
66 \\
653\end{array}$} & \multirow{2}{*}{$\begin{array}{c}2 \\
27 \\
7\end{array}$} & \multirow[t]{2}{*}{3} & \multirow{2}{*}{$\begin{array}{c}1 \\
82\end{array}$} & \multirow{2}{*}{$\frac{2}{42}$} & \multirow{2}{*}{$\frac{3}{22}$} & \multirow{2}{*}{$\begin{array}{c}\mathbf{1} \\
148\end{array}$} & \multirow{2}{*}{$\frac{2}{69}$} & & & \\
\hline Vücuda Uygun Giysi & $\mathrm{S}$ & & & & & & & & & 30 & \multirow{2}{*}{3.440} & \multirow{2}{*}{.179} \\
\hline Olmamasi & $\%$ & & 26.7 & 7.9 & 56.1 & 28.7 & 15.0 & 59.9 & 27.9 & 12.1 & & \\
\hline Çalışma Ortamına Uygun & $\mathrm{S}$ & 39 & 47 & 15 & 64 & 61 & 21 & 103 & 108 & 36 & \multirow{2}{*}{0.708} & \multirow{2}{*}{.702} \\
\hline Kiyafet Olmaması & $\%$ & 38.6 & 46.5 & 14.9 & 43.8 & 41.8 & 14.4 & 41.7 & 43.7 & 14.6 & & \\
\hline Kumaş Kalitelerinin İyi & $\mathrm{S}$ & 44 & 41 & 16 & 59 & 59 & 28 & 103 & 100 & 44 & \multirow{2}{*}{0.516} & \multirow{2}{*}{.773} \\
\hline Olmamasi & $\%$ & 43.6 & 40.6 & 15.8 & 40.4 & 40.4 & 19.2 & 41.7 & 40.5 & 17.8 & & \\
\hline Modaya & $\mathrm{S}$ & 32 & 47 & 22 & 33 & 71 & 42 & 65 & 118 & 64 & \multirow{2}{*}{3.050} & \multirow{2}{*}{.218} \\
\hline Olmamas1 & $\%$ & 31.7 & 46.5 & 21.8 & 22.6 & 48.6 & 28.8 & 26.3 & 47.8 & 25.9 & & \\
\hline Hamile $\quad$ Giysilerinin & $\mathrm{S}$ & 59 & 33 & 9 & 94 & 39 & 13 & 153 & 72 & 22 & \multirow{2}{*}{0.994} & \multirow{2}{*}{.608} \\
\hline Pahalı Olması & $\%$ & 58.4 & 32.7 & 8.9 & 64.4 & 26.7 & 8.9 & 61.9 & 29.1 & 8.9 & & \\
\hline Hamile $\quad$ Giysilerinin & $\mathrm{S}$ & 28 & 55 & 18 & 62 & 58 & 26 & 90 & 113 & 44 & \multirow{2}{*}{6.797} & \multirow{2}{*}{.079} \\
\hline İhtiyaçı Karşılamaması & $\%$ & 27.7 & 54.5 & 17.8 & 42.5 & 39.7 & 17.8 & 36.4 & 45.7 & 17.8 & & \\
\hline Hamile $\quad$ Giysilerinin & $\mathrm{S}$ & 29 & 56 & 16 & 48 & 72 & 26 & 77 & 128 & 42 & \multirow{2}{*}{0.901} & \multirow{2}{*}{.637} \\
\hline Fonksiyonel Olmaması & $\%$ & 28.7 & 55.4 & 15.8 & 32.9 & 49.3 & 17.8 & 31.2 & 51.8 & 17.0 & & \\
\hline Organik $\quad$ Giysi & $\mathrm{S}$ & 37 & 48 & 16 & 44 & 59 & 43 & 81 & 107 & 59 & & 017 \\
\hline Bulunmaması & $\%$ & 36.6 & 47.5 & 15.8 & 30.1 & 40.4 & 29.5 & 32.8 & 43.3 & 23.9 & 0.090 & .04I \\
\hline Tarzıma Uygun Hamile & $\mathrm{S}$ & 37 & 43 & 21 & 63 & 57 & 26 & 100 & 100 & 47 & & 500 \\
\hline Giysisinin Olmamas & $\%$ & 36.6 & 42.6 & 20.8 & 43.2 & 39.0 & 17.8 & 40.5 & 40.5 & 19.0 & 1.090 & .580 \\
\hline Renk Seçeneğinin Fazla & $\mathrm{S}$ & 35 & 46 & 20 & 69 & 52 & 25 & 104 & 98 & 45 & 72 & 137 \\
\hline Olmamasi & $\%$ & 34.7 & 45.5 & 19.8 & 47.3 & 35.6 & 17.1 & 42.1 & 39.7 & 18.2 & 3.912 & .131 \\
\hline Model Seçeneğinin Fazla & $\mathrm{S}$ & 38 & 48 & 15 & 80 & 48 & 18 & 118 & 96 & 33 & 310 & 040 \\
\hline Olmamasi & $\%$ & 37.6 & 47.5 & 14.9 & 54.8 & 32.9 & 12.3 & 47.8 & 38.8 & 13.4 & 8.310 & .040 \\
\hline Hamile Giysi Satan & $\mathrm{S}$ & 49 & 41 & 11 & 85 & 40 & 21 & 134 & 81 & 32 & & \\
\hline $\begin{array}{l}\text { Mağazaların } \\
\text { Sayıda Olmaması }\end{array}$ & $\%$ & 48.5 & 40.6 & 10.9 & 58.2 & 27.4 & 14.4 & 54.3 & 32.8 & 13.0 & 4.769 & .092. \\
\hline Online Mağazalardan & $\mathrm{S}$ & 40 & 54 & 7 & 69 & 58 & 19 & 109 & 112 & 26 & & \\
\hline $\begin{array}{l}\text { Alınan } \\
\text { Beklentiyi Karşılamamasılerin }\end{array}$ & $\%$ & 39.6 & 53.5 & 6.9 & 47.3 & 39.7 & 13.0 & 44.1 & 45.3 & 10.5 & 5.377 & .068 \\
\hline
\end{tabular}
$\mathrm{n}: 247$

1.Kat1lyorum 2.K1smen kat1liyorum 3.Katilmiyorum

Hamile kadınların hamile giysisi satın alırken yaşadıkları sorunlara ilişkin bulguların yer aldığı Tablo 4 incelendiğinde, \% 61.9'unun giysilerin pahalı olmas1, \% 59.9'unun vücuda uygun giysi olmaması, \% 54.3’ünün hamile giysi satan mağazaların yeterli sayıda olmaması, \%47.8’inin model seçeneğinin fazla olmaması,\%42.1'inin renk seçeneğinin fazla olmamas1, \%41.7'sinin kumaş kalitesinin iyi olmaması ifadelerinde en fazla yığılmayla 'katıllyorum' seçeneğini tercih ettikleri görülmektedir.

Tyagi ve Singh ise 2017 yılında yapmış oldukları çalışmalarında, günümüzde hamile kadınların hamileliklerini gizlemeye çalışmadıklarını bunun yerine yeni vücut şekillerine uygun giysiler giymeyi tercihettiklerini belirtmektedir. Bu nedenle hamile kadınların kendilerini mutlu hissedebilmelerinde hem ş1k hem de rahat giysiler bulabilmelerinin önemli olduğunu vurgulamaktadır (2017,s.35). Yapılan çalışmada kadınların hamile giysilerinin pahalı olması ve vüvutlarına uygun giysi bulmada sorun yaşadıkları görülmektedir. Çeğindir (2011) çalışmasında, hamile giysilerindeki uyum problemlerinin başlıca nedenin, giysi kalıplarının, standart kum saati vücut şekli ölçülerine göre 
Buluş, H. E., \& Arga Şahinoğlu, M. (2020). Hamile kadınların giyim problemleri ve beklentileri. Journal of Human Sciences, 17(2), 659-672. doi:10.14687/jhs.v17i2.5985

hazırlanması olduğunu ve hamilelikteki fiziksel değişime bağlı beden artışını karşılamak için kalıpların doğru kısımlardan ve yeterli oranda genişletilmediğini belirtmektedir.

Yapılan Ki-Kare analizi sonucunda ise hamile kadınların çalışma durumu ile giysi satın alırken yaşadıkları problemler arasında yer alan kullanılan kumaşların sağlığa zararlı olması (.047) ve model seçeneğinin fazla olmaması (.040) ifadeleri arasında istatistiksel olarak anlamlı bir ilişki olduğu görülmektedir.

Tablo 5: Hamile kadınların hamile giysisi kullanırken yaşadıkları sorunlar

\begin{tabular}{|c|c|c|c|c|c|c|c|c|c|c|c|c|}
\hline \multicolumn{2}{|l|}{ Problem Türü } & \multicolumn{3}{|c|}{ Çalışmayan } & \multicolumn{3}{|c|}{ Çalişan } & \multicolumn{3}{|c|}{ Toplam } & \multirow{2}{*}{$z^{2}$} & \multirow[b]{2}{*}{$\mathrm{p}$} \\
\hline & & 1 & 2 & 3 & 1 & 2 & 3 & 1 & 2 & 3 & & \\
\hline \multirow{2}{*}{$\begin{array}{l}\text { Kumaşların Renklerinin } \\
\text { Solması }\end{array}$} & $S$ & 62 & 21 & 18 & 56 & 49 & 41 & 118 & 70 & 59 & \multirow{2}{*}{12.694} & \multirow{2}{*}{.002} \\
\hline & $\%$ & 61.4 & 20.8 & 17.8 & 38.4 & 33.6 & 28.0 & 47.8 & 28.3 & 23.9 & & \\
\hline \multirow{2}{*}{$\begin{array}{l}\text { Kumaş Kalitesinin İyi } \\
\text { Olmamasi }\end{array}$} & $\mathrm{S}$ & 34 & 53 & 14 & 35 & 82 & 29 & 69 & 135 & 43 & \multirow{2}{*}{3.391} & \multirow{2}{*}{.184} \\
\hline & $\%$ & 33.7 & 52.5 & 13.9 & 24.0 & 56.2 & 19.8 & 27.9 & 54.7 & 17.4 & & \\
\hline \multirow{2}{*}{$\begin{array}{l}\text { Giysilerin Rahat Giyilip } \\
\text { Ç1karılmaması }\end{array}$} & S & 54 & 34 & 13 & 60 & 50 & 36 & 114 & 84 & 49 & \multirow{2}{*}{6.166} & \multirow{2}{*}{.046} \\
\hline & $\%$ & 53.5 & 33.7 & 12.9 & 41.1 & 34.2 & 24.7 & 46.2 & 34.0 & 19.8 & & \\
\hline \multirow{2}{*}{$\begin{array}{lr}\text { Giysinin } & \text { Hareket } \\
\text { Sirasinda } & \text { Rahatsizlık } \\
\text { Vermesi ve } & \text { Hareketi } \\
\text { Kisitlamas1 } & \end{array}$} & $\mathrm{S}$ & 43 & 41 & 17 & 50 & 65 & 31 & 93 & 106 & 48 & \multirow{2}{*}{1.909} & \multirow{2}{*}{.385} \\
\hline & $\%$ & 42.6 & 40.6 & 16.9 & 34.2 & 44.5 & 21.2 & 37.7 & 42.9 & 19.4 & & \\
\hline \multirow{2}{*}{$\begin{array}{lr}\text { Giyside } & \text { Kullanılan } \\
\text { Aksesuarların } & \text { İyi } \\
\text { Olmamasi } & \\
\end{array}$} & S & 40 & 43 & 18 & 46 & 66 & 34 & 86 & 109 & 52 & \multirow{2}{*}{2.065} & \multirow{2}{*}{.356} \\
\hline & $\%$ & 39.6 & 42.6 & 17.8 & 31.5 & 45.2 & 23.3 & 34.8 & 44.1 & 21.1 & & \\
\hline \multirow{2}{*}{$\begin{array}{l}\text { Dikiş Kalitesinin İyi } \\
\text { Olmaması }\end{array}$} & $\mathrm{S}$ & 42 & 46 & 13 & 39 & 68 & 39 & 81 & 114 & 52 & \multirow{2}{*}{9.473} & \multirow{2}{*}{.009} \\
\hline & $\%$ & 41.6 & 45.5 & 12.9 & 26.7 & 46.6 & 26.7 & 32.8 & 46.2 & 21.1 & & \\
\hline \multirow{2}{*}{$\begin{array}{l}\text { Giysilerin } \\
\text { Olmas1 }\end{array}$} & $\mathrm{S}$ & 33 & 51 & 17 & 47 & 58 & 41 & 80 & 109 & 58 & \multirow{2}{*}{4.791} & \multirow{2}{*}{.091} \\
\hline & $\%$ & 32.7 & 50.5 & 16.8 & 32.2 & 39.7 & 28.1 & 32.4 & 44.1 & 23.5 & & \\
\hline
\end{tabular}

$\mathrm{n}: 247$

1.Katiliyorum 2.K1smen kat1liyorum 3.Katilmiyorum

Hamile kadınların hamile giysisi kullanırken yaşadıkları sorunlara ilişkin bulguların yer aldığ1 Tablo 5 incelendiğinde, \%47.8'inin kumaşların renklerinin solması ve \% 46.2'sinin giysilerin rahat giyilip çıkarılmaması ifadelerinde 'katıllyorum' şeklinde görüş bildirdikleri görülmektedir. Diğer ifadelerde ise yığılmanın 'kısmen katıllyorum' seçeneğinde olduğu görülmektedir.

Yapılan Ki-Kare analizi sonucunda ise hamile kadınların çalışma durumu ile giysi kullanırken yaşadıkları problemler arasında yer alan kumaş renklerinin solması (.002), giysinin rahat giyilip çıkarılmaması (.046) ve dikiş kalitesinin iyi olmaması (.009) arasında istatistiksel olarak anlamlı bir ilişki olduğu görülmektedir.

\section{3. Hamilelerin hamile giysilerinde beklentilerine ilişkin bulgular} verilmiştir.

$\mathrm{Bu}$ bölümde hamile kadınların hamile giysilerinden beklentilerine ilişkin bulgulara yer 
Buluş, H. E., \& Arga Şahinoğlu, M. (2020). Hamile kadınların giyim problemleri ve beklentileri. Journal of Human Sciences, 17(2), 659-672. doi:10.14687/ihs.v17i2.5985

Tablo 6: Hamile kadınların hamile giysilerinden beklentileri

\begin{tabular}{|c|c|c|c|c|c|c|c|c|c|c|c|c|}
\hline \multirow{2}{*}{\multicolumn{2}{|c|}{ Beklentiler }} & \multicolumn{3}{|c|}{ Çalışmayan } & \multicolumn{3}{|c|}{ Çalışan } & \multicolumn{3}{|c|}{ Toplam } & \multirow[b]{2}{*}{$z^{2}$} & \multirow[b]{2}{*}{$\mathrm{p}$} \\
\hline & & \multirow{2}{*}{$\frac{1}{75}$} & \multirow{2}{*}{$\frac{2}{15}$} & \multirow{2}{*}{$\begin{array}{c}3 \\
11\end{array}$} & \multirow{2}{*}{$\frac{1}{95}$} & \multirow{2}{*}{$\frac{2}{32}$} & \multirow{2}{*}{$\frac{3}{19}$} & \multirow{2}{*}{$\frac{1}{170}$} & \multirow{2}{*}{$\frac{2}{47}$} & \multirow{2}{*}{$\frac{3}{30}$} & & \\
\hline Hamilelik $\quad$ Sonrasında & $\mathrm{S}$ & & & & & & & & & & \multirow{2}{*}{2.520} & \multirow{2}{*}{.284} \\
\hline Kullanılabilir Olması & $\%$ & 74.2 & 14.9 & 10.9 & 65.1 & 21.9 & 13.0 & 68.8 & 19.0 & 12.1 & & \\
\hline \multirow{2}{*}{$\begin{array}{l}\text { Birden Fazla Kombinde } \\
\text { Kullanabilir Olmas1 }\end{array}$} & $\mathrm{S}$ & 63 & 33 & 5 & 109 & 28 & 9 & 172 & 61 & 14 & \multirow{2}{*}{5.851} & \multirow{2}{*}{.054} \\
\hline & $\%$ & 62.4 & 32.7 & 4.9 & 74.6 & 19.2 & 6.1 & 69.6 & 24.7 & 5.7 & & \\
\hline \multirow{2}{*}{$\begin{array}{l}\text { Giysilerin Kolay Giyilip } \\
\text { Çıkarılması }\end{array}$} & $\mathrm{S}$ & 76 & 20 & 5 & 121 & 18 & 7 & 197 & 38 & 12 & \multirow{2}{*}{2.206} & \multirow{2}{*}{.272} \\
\hline & $\%$ & 75.2 & 19.8 & 5.0 & 82.9 & 12.3 & 4.8 & 79.8 & 15.4 & 4.9 & & \\
\hline \multirow{2}{*}{ Farklı Tasarım Olması } & $\mathrm{S}$ & 40 & 55 & 6 & 74 & 53 & 19 & 114 & 108 & 25 & \multirow{2}{*}{9.039} & \multirow{2}{*}{.011} \\
\hline & $\%$ & 39.6 & 54.5 & 5.9 & 50.7 & 36.3 & 13.0 & 46.2 & 43.7 & 10.1 & & \\
\hline \multirow{2}{*}{ Ş1k ve Estetik Görünmesi } & S & 55 & 40 & 6 & 100 & 32 & 14 & 155 & 72 & 20 & \multirow{2}{*}{9.262} & \multirow{2}{*}{.010} \\
\hline & $\%$ & 54.5 & 39.6 & 5.9 & 68.5 & 21.9 & 9.6 & 62.8 & 29.1 & 8.1 & & \\
\hline $\begin{array}{lll}\text { İnsan } & \text { Sağllğına } & \text { Zarar }\end{array}$ & $S$ & 63 & 34 & 4 & 111 & 28 & 7 & 174 & 62 & 11 & & \\
\hline $\begin{array}{l}\text { Vermeyecek Kumaşlar } \\
\text { Kullanilmasi }\end{array}$ & $\%$ & 62.4 & 33.7 & 3.9 & 76.0 & 19.2 & 4.8 & 70.4 & 25.1 & 4.5 & 6.663 & .036 \\
\hline Modasina & $\mathrm{S}$ & 41 & 51 & 9 & 72 & 60 & 14 & 113 & 111 & 23 & 196 & 334 \\
\hline Olması & $\%$ & 40.6 & 50.5 & 8.9 & 49.3 & 41.1 & 9.6 & 45.7 & 44.9 & 9.3 & 2.190 & \\
\hline & $\mathrm{S}$ & 59 & 31 & 11 & 114 & 23 & 9 & 173 & 54 & 20 & & 004 \\
\hline $110 \mathrm{ggu}$ & $\%$ & 58.4 & 30.7 & 10.9 & 78.1 & 15.7 & 6.2 & 70.0 & 21.9 & 8.1 & 11.009 & .004 \\
\hline Kullanılan Baskıların Kaliteli & $S$ & 56 & 39 & 6 & 88 & 49 & 9 & 144 & 88 & 15 & & 715 \\
\hline & $\%$ & 55.4 & 38.6 & 5.9 & 60.3 & 33.6 & 6.2 & 58.3 & 35.6 & 6.1 & $0.0 / 1$ & 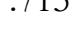 \\
\hline & $\mathrm{S}$ & 71 & 22 & 8 & 118 & 24 & 4 & 189 & 46 & 12 & & \\
\hline Ergonomik Ulmasi & $\%$ & 70.3 & 21.8 & 7.9 & 80.8 & 16.4 & 2.7 & 76.5 & 18.6 & 4.90 & $0.0 / 8$ & (0/9 \\
\hline $\begin{array}{l}\text { Giysilere Ait Bazı Detayların } \\
\text { Değistirilebilir va da Yedek }\end{array}$ & $S$ & 56 & 38 & 7 & 81 & 51 & 14 & 137 & 89 & 21 & & \\
\hline $\begin{array}{l}\text { Parçalarıyla Beraber Satılması } \\
\text { (Yaka, manşet, aksesuar.....) }\end{array}$ & $\%$ & 55.4 & 37.6 & 6.9 & 55.5 & 34.9 & 9.6 & 55.5 & 36.0 & 8.5 & 0.010 & .153 \\
\hline Home $O / m o c 1$ & S & 57 & 42 & 2 & 113 & 25 & 8 & 170 & 67 & 10 & 18786 & 000 \\
\hline 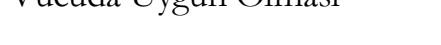 & $\%$ & 56.4 & 41.6 & 2.0 & 77.4 & 17.1 & 5.5 & 68.0 & 27.1 & 4.0 & 10.700 & .000 \\
\hline D & $\mathrm{S}$ & 53 & 42 & 6 & 84 & 50 & 12 & 137 & 92 & 18 & & \\
\hline az dikiş kullanılmas1) & $\%$ & 52.5 & 41.6 & 5.9 & 57.5 & 34.2 & 8.2 & 55.5 & 37.2 & 7.3 & 1.004 & .450 \\
\hline
\end{tabular}

$\mathrm{n}: 247$

1.Katiliyorum 2.Kismen katıliyorum 3.Katilmiyorum

Hamile kadınların hamile giysilerinden genel olarak beklentilerine ilişkin bulguların yer aldığ1 çizelge 6 incelendiğinde, \% 79.8'inin giysilerin kolay giyilip çıarılması, \%76.5'inin giysinin ergonomik olması, \% 70.4'ünün insan sağllğına zarar vermeyecek kumaşlar kullanılması, \%70.0'inin fiyatının uygun olması, \%69.6'sının birden fazla kombinde kullanabilir olmas1, \%68.8'inin hamilelik sonrasında kullanılabilir olması, \%68.0'inin vücuda uygun olması, \%62.8'inin giysinin şık ve estetik görünmesi, \%55.5’inin giysilere ait bazı detayların değiştirilebilir ya da yedek parçalarıyla beraber satılması (yaka, manşet, aksesuar, vb) ve hamile giysilerinin dikişsiz olması (ya da daha az dikiş kullanılması), \%46.20'sinin farklı tasarım olmas1, \%45.70'inin günün modasına uygun olmas1 ifadelerinde 'katıllyorum' şeklinde görüş bildirdikleri görülmektedir.

Shang ve $\mathrm{Hu}$, hamileleğin bir kadının hayatında özel ve önemli bir aşama olduğunu, Hamilelik sırasında kadınlarda meydana gelen fiziksel ve duygusal değişimlerin kadınların giyim tercihleri ve beklentilerinde de değişiklikler meydana getireceğini ifade etmektedir. $\mathrm{Bu}$ dönemde hamile giysilerinin sadece fiziksel değişimi karşılamakla kalmayıp aynı zamanda anne ve bebeğin 

17(2), 659-672. doi:10.14687/jhs.v17i2.5985

sağlığını olumsuz etkilemeyecek materyallerin kullanımının önemine dikkat çekmektedir. (Shang, $\mathrm{Hu}, 2015$, s.187-188). Sarkar ve Rasel ise, çalışmalarında hamile kadınların hamileliğin farklı dönemlerinde sağlıklı ve rahat ancak çok pahalı olmayan giysileri tercih ettiklerini ancak hamilelik döneminde giysilerin rahat, kullanışlı ve ucuz olmasının yanında moda bilincinin gelişmesiyle kadınlar artık hamilelik dönemlerinde şık ve estetik görünmek gibi kaygılar taşıdıklarını da vurgulamaktadır. (Sarkar ve Rasel,2017). Mrzrak ve Güzel'in 2011 yllında yapmış oldukları çalışmalarında hamile kadınların hamile giysisinde en çok tercih ettikleri özelliğin kullanışl11ık olduğu belirlenmiştir. (Mrzrak ve Güzel,2011,s.63).

Yapılan araştırmada da giysilerin kolay giyilip çıkarılması, giysinin ergonomik, insan sağlı̆̆ına zarar vermeyecek kumaşlar kullanılması, fiyatının uygun olması, birden fazla kombinde kullanabilir olması, hamilelik sonrasında kullanılabilir olması, vücuda uygun olması ve giysinin şık ve estetik görünmesi yönündeki beklentilerin ön plana çıktığı görülmektedir.

Yapılan Ki-Kare analizi sonucunda hamile kadınların çalışma durumu ile hamile giysilerden beklentileri arasında yer alan farklı tasarım olması (.011), giysinin uzun süre kullanılabilir olmas1 (.002), giysinin şık ve estetik görünmesi (.010), insan sağlığına zarar vermeyecek kumaşların kullanılmas1 (.036), fiyatının uygun olmas1 (.004) ve giysilerin vücuda uygun olmas1 (.000) ifadeleri arasında istatistiksel olarak anlamlı bir ilişki olduğu görülmektedir.

\section{4) SONUÇ}

Hamile kadınların hamile giysilerine ilişkin tercihleri, sorunları ve beklentilerinin belirlenmesi amacıyla yapılan araştırmada tarama yöntemi kullanılmıştır. Araştırma, Ankara ilinde yaşayan, hamileliklerinin 2. ve 3. trimester dönemlerinde olan toplam 247 kadın üzerinde yürütülmüss ve aşağıdaki sonuçlara ulaşılmıştır.

- Hamile kadınların en çok tercih ettikleri üç giysi türünün pantolon, tayt ve elbise; giysilerde en çok önem verdiği giysi özelliklerinin model, renk, kumaş özelliği, fiyatı, kullanım kolaylı̆̆1, vücuda uyumu ve giysinin rahatllğı olduğu belirlenmiştir.

- Hamile kadınların hamilelik süresince giydikleri giysileri en çok satın alma yoluyla temin ettikleri; giysi satın alırken en sık yaşadıkları problemler arasında giysilerin pahalı olması, vücuda uygun giysi olmamas1, hamile giysi satan mağazaların yeterli sayıda olmaması, model seçeneğinin fazla olmaması, renk seçeneğinin olmaması ve kumaş kalitesinin iyi olmaması; giysi kullanırken en çok kumaşların renklerinin solması ve giysilerin rahat giyilip çıkarılmaması konusunda sorun yaşadıkları belirlenmiştir.

- Hamile kadınların hamile giysilerinden genel beklentilerinin en çok kolay giysilerin kolay giyinilip çıkarılması, ergonomik olması, insan sağlı̆ıına zarar vermeyecek kumaşların kullanılması, fiyatının uygun olması, birden fazla kombinle kullanılabilir olması, hamilelik sonrasında kullanılabilir olması, vücuda uygun olması, dayanıklı olması, șık ve estetik görünmesi ve günün modasına uygun olmasını tercih ettikleri belirlenmiştir.

Araştırmada, kadınların hamile giysilerini çok pahalı buldukları, vücut yapılarına uygun giysiler bulmakta zorlandıkları, hamile giyimi satan mağazaların yetersizliği ve fazla model seçeneğinin bulunmadığı konularında sorun yaşadıkları belirlenmiştir. Kadınların rahat ve mutlu bir hamilelik dönemi geçirmelerinde, kendilerini şık ve rahat hissedecekleri ve anne bebek sağlığını yapısal ve kullanılan materyal açısından olumsuz etkilemeyecek giysiler bulmalarının önemi çok büyüktür. $\mathrm{Bu}$ nedenle hamile giyimi üreten işletmelerin hamile vücut özellikleri ve ölçülerini çok iyi analiz ederek, giysi kalıplarını bu analizlere göre hazırlamaları, günün moda özelliklerini taşıyacak, fonksiyonel ve ergonomik giysiler üretmeleri büyük önem taşımaktadır. Ayrıca hamile giysilerine takıllpçıkarılabilecek parçalar ile kadınlara daha az maliyetle daha fazla model seçeneği sunulabileceği düşünülmektedir. 
Buluş, H. E., \& Arga Şahinoğlu, M. (2020). Hamile kadınların giyim problemleri ve beklentileri. Journal of Human Sciences, 17(2), 659-672. doi:10.14687/ihs.v17i2.5985

\section{KAYNAKÇA}

Aktan, B. (2015). Klinike Pilates Egzersizleri ve Doğuma Hazırlk Eğitiminin Sadece Doğum Eğitimine Göre Doğum Sonuclar Üzerine Etkisi. Yayımlanmamış Yüksek Lisans Tezi, Hacettepe Üniversitesi Sağlık Bilimleri Enstitüsü, Ankara.

Balc1, A. (2005). Sosyal Bilimlerde Araştırma Yöntem, Teknik ve İlkeler. Ankara: Pegem A Yayincilik.

Crane, D. (2003). "Moda ve Gündemleri” Giyimde Sinnf, Cinsiyet Ve Kimlik. (Çev. Ö. Çelik). İstanbul: Ayrint1 Yayınları.

Çeğindir, N. Y. (2011, 4-6 Mayıs). Hamile Kadın Ölçülerinin Vücut Şekillerine Göre İncelenmesi. 4. Uluslararasi Bir Bilim Kategorisi Olarak Kadin: Edebiyat, Dil, Kültür, Sanat, Peyzaj ve Tasarm Calısmalarnda Kadin Semposyumu, Malatya.

Daloğlu, A. , G. (2012). Gebelike ve Depresyonun Bilisssel Isslevler Üzerine Olan Etkisinin Karşılasstrrlması. Yayımlanmamış Uzmanlık Tezi, Atatürk Üniversitesi Ruh Sağlığı ve Hastalıkları Anabilim Dali, Erzurum.

Demircanl, Ü. (1998). Ekolojik Üretim ve Çevre İlişkileri. Tekstil Konfeksiyon, 2, 17-29.

Demirlikan, Ş. (2015). 35 Yas Sonrasinda Hamileliğe Dair Yașantılar: Öznel ve Medikal Bir Deneyim Olarak Hamilelik. Yayımlanmamış Yüksek Lisans Tezi, Okan Üniversitesi Sosyal Bilimleri Enstitüsü, İstanbul.

Günbulut, A. (2016). Antik Dönemden Günümüze Hamile Giysileri. Akdeni乏 Sanat Dergisi, 9(18), $30-49$

Karasar, N. (2014). Bilimsel Arasttrma Yöntemleri. Ankara: Nobel Yayınc1lik.

Koca, E. (2007). Beyin Felçli (SP) Cocuklarm Giyinme Becerilerinde Giysiden Kaynaklanan Problemlerin Belirlenmesi ve Örnek. Bir Uygulama. Yayımlanmamış Doktora Tezi, Gazi Üniversitesi Eğitim Bilimleri Enstitüsü, Ankara.

Mizrak, Ş. ve Güzel, S. (2011). Hamilelerde Giyim Problemleri ve Tercihleri. Electronic Journal of Vocational Colleges, 58-67.

Özdamar, K. (2002). Paket Programlar ile Istatistiksel Veri Analiz̨i. Eskişehir: Etam Matbaa.

Popescu, G., Mocenco, A. ve Olaru, S. Innovative Clothing Design For Women During Pregnancy.

Erişim adresi: http://textile.webhost.uoradea.ro/Annals/Vol\%20XVI-Nr.\%202-2015/Art.nr.113pag.67-72.pdf

Sarkar, J. ve Rasel, S. (2017). Maternity Clothing- A Comprehensive Review. Mart.

Erişim adresi:http://textilefocus.com/maternity-clothing-comprehensive-review/

Selvioğlu, E. (2011). Hamile Giysilerinde Kalp Formundan Kaynaklanan Problemlerin Incelenmesi. Yayımlanmamış Yüksek Lisans Tezi, Gazi Üniversitesi Eğitim Bilimleri Enstitüsü, Ankara.

Shang, Y. ve Hu, X. (2015). Ergonomic maternity dress design. 6th International Conference on Applied Human Factors and Ergonomics (AHFE 2015) and the Affiliated Conferences. S.187-191.

Erişim adresi: file:///C:/Users/dell/Downloads/Ergonomic Maternity Dress Design.pdf

Şen Kilıç, A. , Tama, D. ve Öndoğan, Z. (2014, 2-5 Nisan). Hamile Giysilerinde Karşslaşılan Problemler. XIII. Uluslararası İzmir Tekstil ve Hazır Giyim Sempozyumunda sunuldu, İzmir.

Tyagi, I., and Singh, A. (2017). Designing Fashionable Functional Clothing for Pregnant Women. Journal of Basic and Applied Engineering Research, Volume 4, Issue 1; January-March, pp. 33-35.

TÜİK. Erişim adresi:

http://tuik.gov.tr/PreHaberBultenleri.do;jsessionid=hWRXpRXbQVYWVFv4yh6yqNyY7 NbTIVSnKV7pG4h4g1SLynBn2jbT!460047510?id=30696

Türkdemir, P. (2013). Annelerin 0-2 Yass Bebek Giysilerinde Aradıklar Özellikler. Yayımlanmamış Yüksek Lisans Tezi, Gazi Üniversitesi Eğitim Bilimleri Enstitüsü, Ankara.

Üstdal, M. ve Özgüven, T. (1997). Hekimlikte Biyokimya. İstanbul: Barış Kitapevi.

Üstün, G. , Ağaç, S. ve Yaşar Çeğindir, N. (2006). Hamile Kadınların Giyim Ürünlerinden Beklentileri. Gazi Üniversitesi 12. Ulusal Ergonomi Kongresi. Ergonomi'de Yeni Gelisen Stratejiler Teknolojiler ve Sektörel Uygulamalar Bildiriler, Ankara 


\section{Extended English Summary}

As one of the most visible forms of consumption, clothing has an important role in the formation of identity. Fashion trends and social factors play a role in revealing the identity of individuals. In dress preferences, social factors such as people's social environment, life styles, personality characteristics, family, as well as economic, technological and political factors come to the fore. Furthermore, clothing is one of the important factors reflecting social status. Clothing reveals the identity of people; In addition, when it is considered in terms of its aesthetic, functional and design effects in the individual, it is among the ergonomic terms. Clothing, which has a significant place in human life, emerges as an important concept during pregnancy.

Pregnancy period is an important and special process due to the physiological, psychological, social changes that occur before and after birth, and the change in body appearance. In this period, it is crucial that the woman, whose body changes, especially in the later months of pregnancy, finds clothes that will make her feel stylish, comfortable and happy.

During pregnancy, a visible change occurs in the physical appearance of a woman's body. The most apparent change is significant weight gain, enlargement of the abdomen, thickening of the trunk, hips and limbs. While women do not need clothes until the first three or four months during pregnancy, they need pregnant clothes due to weight gain and physical changes in the next period. Clothing which is suitable for this changing body structure must be worn. In this period, the use of clothes suitable for changing body structure has a great effect on maternal and infant health. Besides, looking good during pregnancy will help the person feel better in every respect. Women determine their clothes in this period, as always, depending on their social status, personal characteristics, age, education and economic opportunities. The most significant point in this regard is that every woman can easily access the clothes that suit their gratification, need and budget and make the right choices accordingly.

The number of infants born alive in Turkey is 1 million 248 thousands and 847 in 2018. Considering that the annual total number of pregnant women in Turkey is about 1 million, it can be suggested in this regard that this number is well significant to be regarded as an important amount of consumer group that needs special clothing designed in the form of functional clothing. Also, it can be added that it constitutes an important market of maternity wear in Turkey.

The aim of this study is to the preferences, problems and expectations of pregnant women regarding pregnant clothes. The research is important in terms of raising awareness about the problems that pregnant women have about clothing during pregnancy. In addition, the fact that it guides the enterprises producing pregnant clothes increases the importance of the study.

Screening method was utilized in this study, which aims to determine the types of clothes that pregnant women prefer during pregnancy, the problems they experience while buying and using clothes, and their expectations from maternity clothes.

The population of the study is pregnant women living in Ankara, whereas the sample is 247 pregnant women living in Ankara selected by purposive sampling method. 146 of them are employed and 101 are unemployed.

In the research, a questionnaire was prepared in order to determine the types of clothes preferred by pregnant women during their pregnancy, ways to provide maternity clothes, clothes characteristics they prefer in pregnant clothes, the problems they experience while purchasing and using clothes, and their expectations from pregnant clothes. The data obtained were analyzed using the Social Sciences Package (IBM SPSS Statistics 20.0). Frequency and percentage distributions of the data obtained through the survey are given in cross tables. A chi-square relationship analysis was applied to measure the statistical relationship between the employment status variable of pregnant women and the types of clothing, the problems they experience when purchasing and using clothes, and their expectations from pregnancy clothes.

In the study, it was found that the participant women regarded pregnancy clothes as very expensive, they had difficulties in finding clothes suitable for their body structures, and that they 
had problems with the insufficiency of shops selling pregnancy clothes and the lack of excess models. It is very important for women to have a comfortable and happy pregnancy period, to find clothes that will feel stylish and comfortable and that will not negatively affect the health of mother and infant in terms of structural and material used. Thus, it is very important for the companies producing pregnancy clothing to analyze pregnant body features and sizes and to prepare the clothing patterns according to these analyzes, to produce functional and ergonomic clothing which have fashion features of the day. In addition, it is suggested that women can be offered more models at less cost with the parts that can be attached to and removed from their pregnancy clothes. 